\title{
THERMAL AND MECHANICAL SHOCKS AFFECTING THE FIRST FLUSH OF PRODUCTION OF LENTINULA EDODES ON EUCALYPTUS SALIGNA LOGS*
}

\section{Humberto Franco Shiomi ${ }^{1}$; Marli Teixeira de Almeida Minhoni2 ${ }^{2 * *}$; José Octávio Machado ${ }^{3}$; Alberto Cargnelutti Filho ${ }^{4}$}

${ }^{1}$ Faculdade de Ciências Agronômicas, Universidade Estadual Paulista, Botucatu, SP, Brasil; ${ }^{2}$ Departamento de Produção Vegetal, Faculdade de Ciências Agronômicas, Universidade Estadual Paulista, Botucatu, SP, Brasil; ${ }^{3}$ Departamento de Produção Vegetal, Faculdade de Ciências Agrárias e Veterinárias, Universidade Estadual Paulista, Jaboticabal, SP, Brasil; ${ }^{4}$ Departamento de Ciências Exatas, Faculdade de Ciências Agrárias e Veterinárias, Universidade Estadual Paulista, Jaboticabal, SP, Brasil

Submitted: March 03, 2006; Returned to authors for corrections: June 01, 2006; Approved: February 23, 2007.

\begin{abstract}
The aim of this work was to evaluate the effect of thermal and mechanical shocks on the productivity of Lentinula edodes colonized on 140 Eucalyptus saligna logs at different immersion times in water and in the first flush of production. The logs were immersed in water at low temperature $\left(16^{\circ} \mathrm{C}\right)$ or environmental temperature $\left(22^{\circ} \mathrm{C}\right)$, for $6,10,14,18,22,26$ and 38 hours. The mechanical shock treatment was accomplished by dropping the logs onto the floor three consecutive times, in a vertical position. Water temperature and immersion time affected L. edodes yield, which increased two to four times when the logs were immersed in cool water for the shortest times (6 and 10 hours). The mechanical shock treatment did not increase the sporophore yield.
\end{abstract}

Key words: shiitake, stress factors, Lentinula edodes, sporophore yield

Shiitake, or Lentinula edodes [(Berk.) Pegler], is one of the most important edible mushrooms in Asian countries, and the second-most cultivated in the world (3).

Traditionally, Shiitake has been produced on recently felled logs measuring $1.0 \mathrm{~m}$ in length by 10 to $15 \mathrm{~cm}$ in diameter. Among the plant species more frequently used in cultivation, eucalyptus logs are particularly important and are predominantly used in Brazil, since they are inexpensive and can be easily purchased (6).

The production of sporophores starts when the logs are completely colonized by the fungus. Under natural conditions, production occurs right after the opening rains, causing complete log wetting and a sudden temperature decrease in the environment $(5,16)$. Under business growing conditions, these changes are provoked and managed, and include a reduction in temperature and increases in moisture, aeration, and luminosity, causing the fungus metabolism to change and forcing it to reallocate its energy sources to the production of mushrooms (15). The management intended to induce the production of sporophores is usually made by immersing the logs in water, which is frequently cooled to create an additional stress factor for the mycelium (5). Generally, most Shiitake strains respond better to induction when submerged in water at a temperature between $5^{\circ} \mathrm{C}$ and $20^{\circ} \mathrm{C}(5,10,16)$, with a water immersion time between 8 and 72 hours (12), with longer immersion times required for logs with greater diameters or densities (16).

The mechanical shock consists in exposition of the logs to strong impacts at one end, after they are removed from the immersion tank. Its use dates from the eleventh century in China, where it was observed that, under natural conditions, when the logs were vigorously stricken, after a few days the Shiitake mushrooms would appear abundantly on them (2). This practice was widely used years ago, however, without experimental data (14). No detailed studies were found on the effects of water

\footnotetext{
*Paper presented to Faculdade de Ciências Agrárias e Veterinárias - UNESP, Campus de Jaboticabal, para graduação em Agronomia, $1^{\circ}$ semestre de 1998.

**Corresponding Author. Mailing address: Departamento de Produção Vegetal - FCA - UNESP - Fazenda Experimental do Lageado s/n cep 18603-970

- Botucatu, SP - Brasil. Tel.: (14) 3811-7205. E-mail: marliminhoni@fca.unesp.br
} 
temperature and log immersion time, or yet on the effect of mechanical shock on the induction of $L$. edodes primordia formation on eucalyptus logs.

The experiment was conducted under greenhouse conditions, in Jaboticabal, São Paulo, Brazil. The treatments were arranged in a completely randomized design, with five replicates, in a $7 \times 2 \times 2$ factorial arrangement (seven times of immersion in water; two immersion water temperatures; with or without mechanical shock). The production of inoculum was based on the JAB-K1 L. edodes strain, cultivated in PDA medium for 10 days at $25^{\circ} \mathrm{C}$. The inoculum was grown on a substrate previously sterilized consisting of Eucalyptus sp. sawdust, rice bran, and water $(4: 1: 1 \mathrm{v} / \mathrm{v})$, placed inside 1-liter capacity polypropylene bags and incubated in an oven at $25^{\circ} \mathrm{C}$ for 30 days.

One hundred and forty Eucalyptus saligna logs 10 to $15 \mathrm{~cm}$ in diameter and $1 \mathrm{~m}$ in length, were inoculated with the substrate colonized by the fungus two days after the trees were cut. The $\operatorname{logs}$ were then inoculated with $L$. edodes, using a mechanical inoculator, after drilling the logs with a high-rotation (7000 rpm) power drill; a spacing of $15 \mathrm{~cm}$ between holes and $5 \mathrm{~cm}$ between hole rows was adopted, totaling $50 \pm 10$ holes per log. The holes were drilled at a $2 \mathrm{~cm}$ depth with a diameter of $1.2 \mathrm{~cm}$, according to the methodology described by Przybylowicz and Donoghue (5). After inoculation, the logs were disposed at random, stacked at an angle, with a height of $120 \pm 10 \mathrm{~cm}$, separated at $3.0 \mathrm{~cm}$ to $5.0 \mathrm{~cm}$ from one another, in a shed protected from direct sunlight, at a temperature near $25 \pm 2^{\circ} \mathrm{C}$ and relative humidity from $60 \%$ to $75 \%(15,23)$, for a period of 170 days until the formation of sporophores was induced.

The $140 \operatorname{logs}$ were arranged horizontally inside two empty masonry tanks and tied to the bottom of the tank with a metal chain. In one tank, seventy logs were immersed in water at a temperature of $16^{\circ} \mathrm{C}$, achieved by adding block ice. This temperature was $10^{\circ} \mathrm{C}$ below room temperature $\left(26^{\circ} \mathrm{C}\right)(12,13)$, and was maintained cool throughout the treatments by adding ice blocks whenever needed. The other 70 logs were immersed in water at a temperature of $22^{\circ} \mathrm{C}$, using the same procedures, but without cooling the water. In both tanks, the water immersion times were $6,10,14,18,22,26$, and 38 hours.

After each immersion period, the logs were removed from the tanks and submitted or not to mechanical shock. The mechanical shock consisted of strong impacts at one end of the $\log$, obtained by dropping the log three consecutive times, in the vertical position, against a steady shield on the floor, from a height of $30 \mathrm{~cm}$. After the treatments were carried out, the logs were transferred to an environment favorable for the development of sporophores $\left(90 \pm 5 \% \mathrm{RH}, 20 \pm 2^{\circ} \mathrm{C}\right.$, and $500 \pm$ 200 lux) $(5,16)$. The harvest period was from 5 to 8 days after induction. Harvest was accomplished by hand and the standard adopted for the sporophores was the same required by the consumer market, i.e., sporophores with the pileus completely expanded and with the edges still facing down (13). After harvest, the sporophores fresh mass per log, number of sporophores per $\log$, and fresh mass per sporophore were determined. The data were submitted to analysis of variance and the $\mathrm{F}$ test at $5 \%$ probability, and regression equations were fitted.

The coefficient of variation oscillated between $66.36 \%$ (fresh mass per sporophore) and $102.60 \%$ (sporophore fresh mass per $\log$ ), revealing high variability between replicates of the same treatment (Table 1). The irregular sporophores yield distribution and the inclusion of data from unproductive or little productive $\operatorname{logs}$ in the statistical analysis explain these results. According to Royse (7), this irregular yield distribution is a common fact in the cultivation of L. edodes on logs. Montini and Eira (4) also adopted this procedure, because the exclusion of unproductive $\log$ data in order to decrease the experimental error would result in an incorrect representation of reality.

With respect to the production of sporophores fresh mass per log, number of sporophores per log, and fresh mass per sporophore, there were no interactions between the factors immersion time (IT), water temperature (WT), and mechanical shock (MS), demonstrating that the behavior of one factor is not influenced by changes in another factor. The immersion water temperature (WT) effect was significant in relation to the production of $L$. edodes sporophores fresh mass per log, number of sporophores per $\log$, and fresh mass per sporophore (Table 1). In cooled water $\left(16^{\circ} \mathrm{C}\right)$, the sporophores fresh mass per log, number of sporophores per log, and fresh mass per sporophore were, respectively, about four, four, and two times higher than those obtained in water without cooling $\left(22^{\circ} \mathrm{C}\right)$, demonstrating that temperature reduction favors the development of $L$. edodes, and therefore is an adequate technique to increase yield. Similar results were obtained by Song et al. (10), who observed $L$. edodes dry weight and sporophores production velocity increases on solid and semi-solid artificial substrates, with water cooled to $5^{\circ} \mathrm{C}$ in relation to the control $\left(25^{\circ} \mathrm{C}\right)$ for 24 hours. These authors verified an alteration in the metabolism of the fungus, caused by a change in the profile of mycelium lipids, mainly due to an increase in the quantity of unsaturated fatty acids, such as linoleic acid, which would be the correct substrate for primordia initiation $(8,11)$; this change seems to have favored the formation of sporophores. Studies have demonstrated the capacity of the low temperature stress factor in changing the composition of fatty acids in other microorganisms (17), causing an increase in the amount of unsaturated fatty acids, such as palmitoleic, linoleic, and oleic acids, which are presumed to act maintaining the fluidity of the lipid on the L. edodes membrane (8) and favoring the production of sporophores. The mechanical shock effect was non-significant, indicating that it does not change sporophores fresh mass per log, number of sporophores per log, and fresh mass per sporophore. Therefore, it did not prove to be an effective technique to increase sporophores productivity (Table 1). 
Table 1. Values for the F Test statistic of causes of variation in the analysis of variance with regard to sporophores fresh mass per $\log$, number of sporophores per log, and fresh mass per sporophore, in L. edodes mycelia submitted to seven immersion times, two water temperatures, and two mechanical shocks (five logs per treatment).

\begin{tabular}{lccc}
\hline Causes of variation & $\begin{array}{c}\text { Sporophores fresh } \\
\text { mass per } \log \left(\mathrm{g} \log ^{-1}\right)\end{array}$ & $\begin{array}{c}\text { Number of sporophores } \\
\text { per } \log \left(\mathrm{units} \log { }^{-1}\right)\end{array}$ & $\begin{array}{c}\text { Fresh mass per } \\
\text { sporophore }(\mathrm{g} \text { sporophore }\end{array}$
\end{tabular}

* Significant at the $5 \%$ probability level; ** Significant at the $1 \%$ probability level; ${ }^{\text {Ns }}$ Non significant.

The L. edodes sporophores fresh mass per log, number of sporophores per log, and fresh mass per sporophore on eucalyptus logs showed a decreasing exponential behavior as immersion time in water increased. These results demonstrate that a yield reduction occurred with longer times of immersion in water. However, it must be taken into consideration that primordia formation is the most sensitive stage to environmental influences, where extreme log moisture, temperature, and relative humidity values may change or inhibit the production of sporophores $(5,16)$. Thus, the excess moisture contained in the logs, resulting from prolonged exposures to water, could be the reason for the systematic drop in sporophores yield, as immersion times became longer.

Under the conditions the experiment was developed, on the first flush of production, the cooling of the immersion water significantly increases the production of Lentinula edodes sporophores on Eucalyptus saligna logs (2 to 4 times); mechanical shock does not influence the production of Lentinula edodes sporophores on Eucalyptus saligna logs and the prolonged exposure of Eucalyptus saligna logs in water decreases the production of Lentinula edodes sporophores.

\section{RESUMO}

\section{Coque térmico e mecânico afetando o primeiro fluxo de produção de Lentinila edodes em toras de Eucalyptus saligna}

O objetivo deste trabalho foi avaliar o efeito do choque térmico e mecânico na produtividade de Lentinula edodes em 140 toras de Eucalyptus saligna, completamente colonizadas pelo fungo, em diferentes tempos de imersão em água e no primeiro fluxo de produção. As toras foram imersas em água resfriada $\left(16^{\circ} \mathrm{C}\right)$ ou à temperatura ambiente $\left(22^{\circ} \mathrm{C}\right)$; os períodos de imersão corresponderam a 6, 10, 14, 18, 22, 26 e 38 horas; o choque mecânico foi acompanhado por três quedas consecutivas da tora, em posição vertical, no chão. A temperatura da água e o tempo de imersão afetaram a produção de L. edodes, resultando em aumentos significativos ( 2 a 4 vezes) nos tratamentos em que as toras foram submetidas à água resfriada e nos tempos de imersão mais curtos (6 e 10 horas). O choque mecânico não resultou em aumento na produção de basidiomas.

Palavras-chave: Shiitake, fatores de estresse, Lentinula edodes, produção de basidiomas

\section{REFERENCES}

1. Chang, S.T.; Miles, P.G. (2004). Mushrooms: Cultivation, Nutritional Value, Med. Effect Environ. Impact. $2^{\text {nd }}$ ed. CRC Press.

2. Chen, A.W. (2005). What is Shiitake? In: Mushroom Grower's Handbook 2, MushWorld, Seoul, p.3-16.

3. Miles, P.G.; Chang, S.T. (1997). Genetics of fungi. In: Miles, P.G.; Chang, S.T. Mushroom biology: concise basics and current developments. World Scientific: Singapura, p.65-82.

4. Montini, R.M.; Eira, A.F. (1998). Efeito do período de incubação e diâmetro de toras de Eucalyptus saligna Sm na produtividade de shiitake (Lentinula edodes (Berk.) Pegler), no primeiro choque de indução. Energ. Agric., 13(4): 23-31.

5. Przybylowicz, P.; Donoghue, J. (1988). Shiitake Growers Handbook. The Art and Science of Mushroom Cultivation. Kendall/Hunt Publishing Company: Dubuque, 217p.

6. Queiroz, E.C.; Marino, R.H.; Eira, A.F. (2004). Mineral supplementation and productivity of the shiitake mushroom on eucalyptus logs. Sci. Agric., 61(3): 260-265.

7. Royse, D.J. (1985). Effect of spawn run time and substrate nutrition on yield and size of shiitake mushroom. Mycologia, 77(5): 756-762.

8. Sakai, H.; Kajiwara, S. (2004). Membrane lipid profile of an edible basidiomycete Lentinula edodes during growth and cell differentiation. Lipids, 39(1): 67-73. 
9. San Antonio, J.P. (1983). Spawn disk inoculation of logs to produce mushrooms. Hortscience, 18(5): 708-710.

10. Song, C.H.; Cho, K.Y.; Nair, N.G. (1991). Effect of low temperature shock treatment on sporophore initiation, lipid profile and nutrient transport in Lentinus edodes. Mycologia, 83(1): 24-29.

11. Song, C.H.; Cho, K.Y.; Nair, N.G. (1987). A synthetic medium for the production of submerged cultures of Lentinus edodes. Mycologia, 79(6): 866-876.

12. Stamets, P.; Chilton, J.S. (1983). The Mushroom Cultivator (A Practical Guide to Growing Mushroom at Home). Agarikon Press: Washington, 415p.
13. Teixeira, E.M. (2000). Caracterização isoenzimática e molecular de Lentinula edodes e avaliação da produção em função da espécie de eucalipto e clima. Araraquara, 123p. (D. Thesis. Instituto de Química, UNESP).

14. Teixeira, E.M.; Machado, J.O. (1997). O cultivo do cogumelo shiitake em cepos. FUNEP: Jaboticabal, 44p.

15. Tokimoto, K.; Fukuda, M. (1997). Changes in enzyme activities in bedlogs of Lentinula edodes accompanying fruit body development Mokuzai Gakkaishi, 43: 444-449.

16. Tokimoto, K. (2005). Shiitake Log Cultivation. In: Mushroom Grower's Handbook 2, MushWorld: Seoul, p.56-73.

17. Walker, G.M. (1998). Yeast Phisiology and Biotechnology. John Wiley \& Sons: London, p.101-202. 